\title{
PW01-024 - Phenotypic analysis of a MEFV negative FMF cohort
}

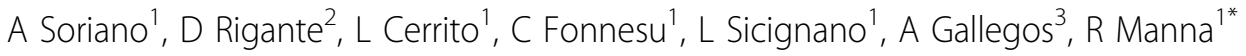 \\ From 7th Congress of International Society of Systemic Auto-Inflammatory Diseases (ISSAID) \\ Lausanne, Switerland. 22-26 May 2013
}

\section{Introduction}

Familial Mediterranean fever (FMF) is an inherited autosomal recessive disorder, ethnically restricted and commonly found among individuals of Mediterranean descent, caused by MEditerranean FeVer gene (MEFV) mutations on the chromosome 16. It is the most frequent periodic febrile syndrome among autoinflammatory syndromes. Eighty \% of patients with FMF have $M E F V$ mutations, while around $20 \%$ do not have mutations.

\section{Objectives}

We analysed epidemiological and clinical characteristics, as well as treatment schedules of a large cohort of FMF patients without any $M E F V$ mutations, who responded to colchicine, in order to identify further clinical features of this specific subgroup.

\section{Methods}

Epidemiological and clinical details of 344 patients attending the Periodic Fevers Research Centre in a period of 15 years were analysed. We selected patients without $M E F V$ mutations, in whom diagnosis was established by the Tel-Hashomer criteria. We finally compared the clinical findings of $M E F V$-negative population with the $M E F V$-positive one.

\section{Results}

Genetic testing by $M E F V$ analysis was performed in all patients $(\mathrm{n}=344) ; 41$ patients $(14 \%, 20$ males and 21 females) negative for $M E F V$ mutations were selected and studied. Similarly with $M E F V$ positive patients, in our case-series, most $M E F V$-negative ones came from Southern and Central Italy. The mean age of FMF onset was 21.8 years, differently from what observed in
$M E F V$-positive population, in which the mean age was 15. The frequency of attacks went from less than 1 attack/month (in 26\%) to 1-2 attacks/month (in 54\%) and more than 2 attacks/months (in 19.5\%). The mean duration of each attack was $83.9 \pm 8.91$ hours. The typical clinical signs of FMF attacks were: fever ( $\mathrm{T}$ max $39.4^{\circ} \mathrm{C} \pm 0.12$, present in $100 \%$ of patients), articular pain (76\%), abdominal pain (63.4\%), oral aphthosis (44\%), and chest pain (37\%). Thirty-one out of 41 patients had joint involvement in terms of arthritis (21.5\%), arthralgias (25\%), arthromyalgias (32\%), and myalgias (21.5\%). Attacks were controlled with a mean dose of colchicine of $1.5 \mathrm{mg} /$ day in all patients (vs a mean dose of $1.3 \mathrm{mg} / \mathrm{die}$ in the $M E F V$-positive population). No statistically significant difference was detected in terms of frequency and duration of attacks, as well as in symptoms distribution and colchicine dosage between $M E F V$-negative and positive populations.

\section{Conclusion}

Analysis of our MEFV-negative series of Italian patients revealed a higher prevalence of late-onset FMF, whereas the percentage distribution of symptoms was similar to $M E F V$-positive patients. These results support the hypothesis of involvement of other low-penetrance genetic systems in the FMF clinical expression.

\section{Disclosure of interest}

None declared.

\section{Authors' details}

'Periodic Fevers Research Centre, Catholic University of Sacred Heart, Rome, Italy. ${ }^{2}$ Department of Pediatrics, Catholic University of Sacred Heart, Rome, Italy. ${ }^{3}$ Nuestra Senora del Prado Hospital, Talavera de la Reina, Spain. 


\section{References}

1. Soriano A, Manna R: Familial Mediterranean fever: new phenotypes. Autoimmun Rev 2012, 12:31-7.

2. Rigante $D$ : The fresco of autoinflammatory diseases from the pediatric perspective. Autoimmun Rev 2012, 11:348-56.

3. Manna R, Cerquaglia C, Curigliano V, Fonnesu C, Giovinale M, Verrecchia E, Montalto M, De Socio G, Soriano A, La Regina M, Gasbarrini G: Clinical features of familial Mediterranean fever: an Italian overview. Eur Rev Med Pharmacol Sci 2009, 13(Suppl 1):51-3.

doi:10.1186/1546-0096-11-S1-A77

Cite this article as: Soriano et al:: PW01-024 - Phenotypic analysis of a MEFV negative FMF cohort. Pediatric Rheumatology 2013 11(Suppl 1):A77.

Submit your next manuscript to BioMed Central and take full advantage of:

- Convenient online submission

- Thorough peer review

- No space constraints or color figure charges

- Immediate publication on acceptance

- Inclusion in PubMed, CAS, Scopus and Google Scholar

- Research which is freely available for redistribution

Submit your manuscript at www.biomedcentral.com/submit
Ciomed Central 